\title{
Estimation of inter-city travel demand for public road transport in Nigeria
}

\section{Declan Ndukauba Dike, Callistus Chigozie Ibe, Ejem Agwu Ejem, Onyinyechi Erumaka, Oluchi Ebere Chukwu}

Department of Transport Management Technology, Federal University of Technology, Owerri, Imo State, Nigeria

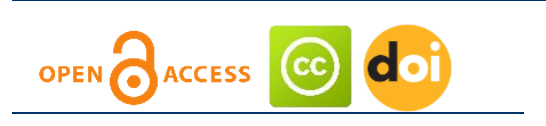

Article history:

Received: April 21, 2018

1st Revision: June 3, 2018

Accepted: November 25,

2018

\section{DOI:}

10.14254/jsdtl.2018.3-3.7

\begin{abstract}
This research develops an urban travel demand model for 19 directional O-D city-pair from Owerri Urban. Using revealed preference data from the period of 2014 to 2016 operated by sixteen transport companies in Owerri, Imo State. Other empirical findings include that; overall fares elasticities are low, so that increases in fare levels will almost always lead to increases in revenue. An empirical model to assess the viability of intercity passenger transport operation in Nigeria was formulated. This study will help the operators in business to do a sensitivity analysis based of changes in the intercity passenger travel markets in Nigeria.
\end{abstract}

Keywords: inter-city, demand, transport, elasticities, passenger.

\section{Introduction}

Intercity travel is the travel between cities or other points of interest that are separated by some significant distance. The transportation literature generally refers to long-distance travel as intercity travel. The term long-distance travel is defined as trips of a certain minimum distance. However, the thresholds for long distance travel in various countries are different. All these values are derived by population surveys. The thresholds can vary from 50 miles (UK) to 100 miles (USA) (Limtanakool, Dijst \& Lanzendorf, 2003). Even within the USA, there exists a plethora of definitions (US DOC, undated). In this study, 100 miles is used to define intercity travel, regardless of any overnight stay.

Intercity travel behavior is different from urban travel behavior in certain aspects, such as travel frequency. However, it still follows the general four-step model for urban travel behavior: trip generation, trip distribution, mode choice, and trip assignment. Intercity travel decision making is typically assumed to consist of trip generation, destination choice, mode choice, and route choice.

Conventional travel demand models separate the demand functions into four steps. When used for intercity travel, the model consists of two sequential steps that predict intercity travel by mode (Koppelman \& Hirsh, 1984). The first step forecasts the total intercity travel volume for city pairs. The second step distributes the volume via a logit model. Typically, the number of trips is formulated as a function of the socioeconomic characteristics of city pairs and composite measures of the level of service. Today these models are still in applications such as forecasting high-speed rail ridership (Brand, Parody, Hsu, \& Tierney, 1992). These models provide some insight into intercity travel behavior. However, the model obscures much of the information in the data. Its behavioral implication that

Corresponding author: Ejem Agwu Ejem

E-mail: ejemflagospel@yahoo.com

This open access article is distributed under a Creative Commons Attribution (CC-BY) 4.0 license. 
individuals decide their travel behavior in stages does not appear to be consistent with reality. Hence, it has limitations as an estimator of intercity travel demand (Peers \& Bevilacqua, 1976).

The estimation of long-term travel demand requires specific modeling which identifies the structural factors of travel. One of the first such factors to be identified was the quantity of goods or services available, be it in private cars (Mogridge, 1967 \& 1989; Evans, 1970; Jansson, 1989; Button et al., 1993; Gakenheimer, 1999; Ortuzar \& Willumsen, 2006; Holmgren, 2007) or in public transportation (Wardman, 2004; Bresson et al., 2003, 2004; Garcia-Ferrer et al., 2006). The literature shows that other structural determinants are also considered, for example the user cost of a trip (McFadden, 1974; Paulley et al., 2006), the income of the household that travels, (Schafer \& Victor, 2000; Dargay \& Hanly, 2002; Medlock \& Soligo, 2002) or the spatial distribution of transportation (Kain and Fauth, 1977; Oum et al., 1992; Giuliano \& Dargay, 2006; Davidson et al., 2007). Moreover, in addition to these structural factors, travel differences between different groups of countries also seem to play a role (Schafer and Victor, 2000; van de Coevering and Schwanen, 2006).

This study describes a demand model based on these structural factors. We have to verify that they are statistically significant and checked whether they have a similar impact on intercity travel in different groups or countries. We have used a robust econometric method (2SLS, SUR, 3SLS2, Chow's stability test, see Greene, 1993; Maddala, 2008) which has, to the best of our knowledge, only occasionally been used in the sphere of transport (apart from by Cervero et al., 2002; Zhou et al., 2008). We have to check whether our findings agree with those in the literature. Previous study results show that two variables stand out from the others: the user cost of trips (by private car and public transport) and urban density. It is these explanatory variables which stand as the best to the various econometric tests which previous studies applied. The value of the elasticity coefficients, moreover, should concur with those in the literature. Furthermore, the estimated demand functions for a given country seem to be independent of the group of countries to which it belongs. This may seem surprising but it can be explained by our inability to take account of urban GDP in a satisfactory manner.

The inter-city urban transport challenge in Nigeria has been posed in this study as one responsible for rapidly growing mass mobility needs, within a context of increasingly constrained resources. We focus on public transit because a significant proportion of trips in the large urban areas are conducted by this mode, and indeed, the poor majority depend on it for their economic survival. And with rapidly growing urban populations, many of whom will likely be poor, the provision of affordable and convenient public transit will continue to be of vital importance for many years to come. Knowledge of travel demand for public transport service is the key to a successful system transformation. There are conscious efforts by the planners in Nigerian road transport industry to expand capacity of the road space. While overestimating future traffic leads to overinvestment, underestimating future traffic distorts system operations and causes traffic congestion, thereby increasing transport costs which means that a better understanding of intercity travel demand will make the expansion more costeffective and beneficial to the to the society. This is presently lacking suggesting that there are problems that need to be identified.

Current understanding of the demand for public transport service fails to address several significant questions: (1) what is the relative importance of causal factors (such as, trip frequency, route distance, journey time, and fare) in determining demand among routes? (2) How have these relationships changed over time? Appropriately identifying causal factors and quantifying their effects contribute to the fundamental understanding of intercity travel demand and allow sensible predictions of demand response to a wide range of future scenarios, including different levels of congestion, network connectivity, vehicle size and frequency, and fuel price, among other factors. Existing models in Nigeria are not sufficient to meet these purposes hence the need to estimate the inter-city travel demand for public road transport in Nigeria.

Most existing models in the literature only deal with geo-economic considerations, or treat these two phenomena sequentially. The sequential approach is inappropriate since it implicitly assumes that the total demand volume is independent of alternative cost and service quality. In addition, studies in intercity travel demand literature usually include cost and frequency as causal factors, other factorssuch as journey time and capacity- are seldom investigated (Camagni et al., 2002). Specifying these additional causal factors not only allows predictions of demand response to changes in these factors, but also affects the estimated effects of cost and frequency of trip. 


\section{Methodology}

Inter-city transport market in this study is divided into 19 origin-destination (O-D) pairs due to data compilation needs. Markets are specified as one directional O-D pairs originating from Owerri Urban to 19 different cities in Nigeria. Inter-city travel choices include multiple products which are unique combinations of cities from Owerri . That is Owerri - Aba, Owerri - Abuja, Owerri - Awka, Owerri - Calabar, Owerri - Enugu, Owerri - Lagos, Owerri - Makurdi, Owerri - Okigwe, Owerri - Portharcourt, Owerri - Uyo, Owerri - Yenegoa, Owerri - Abuja, Owerri - Jos, Owerri - Kaduna, Owerri - Warri, Owerri - Abakaliki, Owerri - Benin, Owerri - Ibadan and Owerri - Sokoto. The map in Figure 1 captures the pictorial view of the city-pairs explored in the study.

\section{Figure 1: Map of Nigeria showing the Origin and Destination (OD) of Travel routes explored in} the study

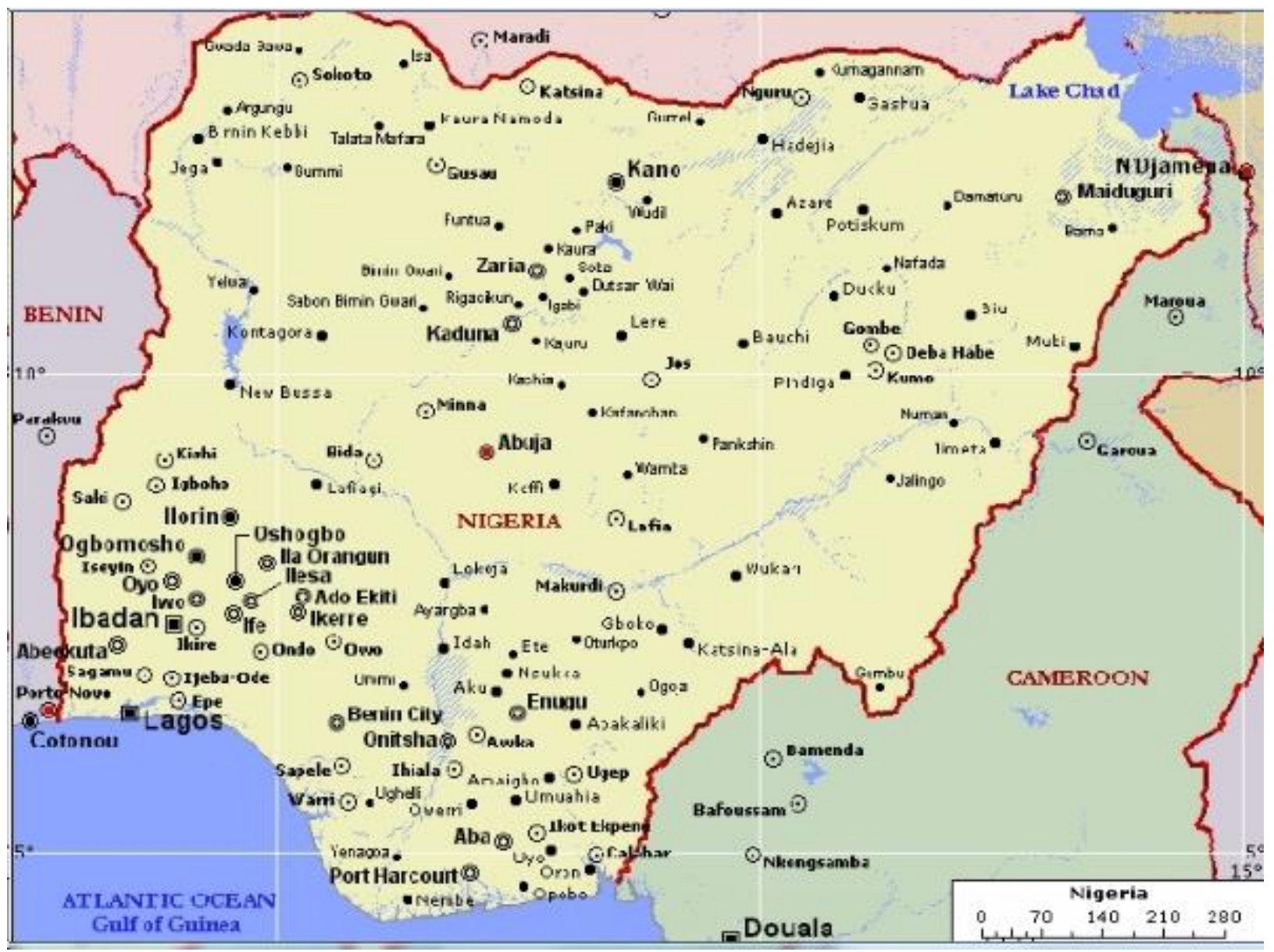

Source: http://www.nigerianmuse.com

Several enumerators were employed at the terminals of the surveyed transport companies at different periods of the day all through the study period of two year. The data collected include the estimated travel times, frequency of trips at various routes, vehicle capacity, fare charged and travel distance. We determine the factors that explain the volume of passenger traffic generated by the bus terminals in Owerri municipality in the period 2013-2015. Demand for urban passenger movement may be influenced by several attributes as identified in literature. Indeed, the amount of passenger traffic that an urban area determined by closely related to frequency of vehicle trips, available bus fare, vehicular capacity, distance between origin and destination and journey time performance of vehicles of respective transport companies. Hence, we estimated an equation that considers the determinants of inter-city urban passenger traffic in the sample of Nigerian bus terminal. The equations to estimate the determinants of demand of inter-city urban passenger traffic in the sample of Owerri bus terminal within the period under paper are as follows. 
Model 1:

$$
\operatorname{In}_{\text {topax }}=\beta_{1} \text { InFreq }+\beta_{2} \text { InFare }+\beta_{3} \text { Dist }+\beta_{4} \text { InJtim }+\varepsilon \text { irt }
$$

Model 2:

$$
\operatorname{In}_{\mathrm{pax}}^{\mathrm{D}}-\mathrm{km}=\beta 1 \text { InFreq }+\beta_{2} \text { InFare }+\beta_{3} \text { Jtim }+\beta_{4} \text { InVcap }+\varepsilon \text { irt }
$$

The explanatory variables are defined as follows:

Freq= represents the frequency of trips at route $\mathrm{r}$;

Fare $=$ available bus fare of route $\mathrm{r}$, which is the same for all routes of the 0-D

city pair at time t served by the same transport company;

Jtim= journey-time performance of vehicle of respective transport company

Dist $=$ distance between origin and destination

Vcap = vehicular capacity

$\mathrm{D}_{\text {totpax }}=$ demand expressed as total number of passengers

$\mathrm{D}_{\text {pax }-\mathrm{km}}=$ demand expressed as passenger kilometer

By treating the regression function coefficients as elasticity coefficients, we estimated a log-linear relationship between travel demand (by public transport) and the explanatory variables of fare, frequency, vehicle capacity, distance and journey. This logarithmic transformation also has the benefit of reducing the risk of heteroskedasticity (Greene, 1993; Bourbonnais, 2004; Maddala, 2008) although it does not completely eliminate it. As stated by Maddala (2008), to estimate a regression model: "One of the assumptions we have made is that errors $u_{\mathrm{i}}$ in the regression equation have a common variance $\sigma^{2}$. This is known as the homoscedasticity assumption. If the error does not have a constant variance, we say they are heteroskedastic" (Maddala, 2008). Thus, heteroskedasticity means that the model is not convergent, which makes it less robust. To estimate the model's unknown parameters, we first of all used the Ordinary Least Square (OLS) method and subjected the estimated variables to multinomial logit model. According to the proposed demand model, the following causal factors were utilized. There are fare, journey time, frequency, market distance, and vehicle capacity.

\section{Model Data}

Inter-city transport market in this paper is divided into 19 origin-destination (O-D) city-pairs due to data compilation needs. Markets are specified as one directional O-D pairs originating from Owerri Urban to 19 different cities in Nigeria. Intercity travel choices include multiple products which are unique combinations of cities from Owerri. Our specification captures these important service attributes of urban transport services. Our data consist of 19 directional 0-D markets and the total number of travel products on the markets filtered is 207 from 16 different transport companies with a terminal base at Owerri.

\section{Table 1: Urban Transport Companies Surveyed}

\begin{tabular}{lccc} 
Transport Company & Frequency & Percent & Cumulative Percent \\
\hline ABC & 24 & 11.6 & 11.6 \\
ABIA CITY & 25 & 12.1 & 23.7 \\
ABIA LINE & 16 & 7.7 & 31.4 \\
AITC & 2 & 1.0 & 32.4 \\
CHISCO & 7 & 3.4 & 48.7 \\
CONSTANTLINK & 26 & 12.3 & 53.1 \\
GOD IS GOOD & 10 & 4.8 & 75.4 \\
GUO & 46 & 22.2 & 76.8 \\
HEARTLAND EXPRESS & 3 & 1.4 & 77.8 \\
IMO EXPRESS & 2 & 1.0 & 83.1 \\
ITC & 11 & 5.3 & 84.1 \\
LIBRA & 2 & 1.0 & 85.0 \\
MULTILINE & 2 & 1.0 & 91.3 \\
PMT & 13 & 6.3 & 98.6 \\
TRACAS & 15 & 7.2 & 100.0 \\
YOUNGS & 3 & 1.4 & \\
\hline TOTAL & $\mathbf{2 0 7}$ & $\mathbf{1 0 0 . 0}$ & \\
\hline
\end{tabular}


After the data were filtered based on the criterion of retaining routes with at least 2 daily trip frequency, 207 daily route observations to estimate the model. The statistics for variables are computed using data of different time periods from 2014 to 2016. Market level variables, which are used to explain total demand of urban transport, are identical for all similar city-pair of a market. The statistics for these variables, therefore, are presented in terms of routes. The data used for estimating the model is filtered, in order to simplify the empirical work and ensure reliable data. This research uses Owerri based itineraries with non-zero fares.

\section{Model estimation}

The basic strategy for estimating aggregate intercity travel demand models is to transform market share functions and then estimate parameters by linear regression. For the econometric models, the patronage of route is the basic determinant of demand. The natural logarithms of intercity travel market shares of two demand models are explored. We attempt to identify factors that explain the volume of passenger traffic generated by the bus terminals in Owerri municipality in the period 2013-2015. Demand for urban passenger movement may be influenced by several attributes. Indeed, the amount of passenger traffic that an urban area can generate is closely related to frequency of vehicle trips, available bus fare, vehicular capacity, distance between origin and destination and journey time performance of vehicles of respective transport companies.

Hence, we estimate an equation that considers the determinants of urban passenger traffic in the sample of Nigerian bus terminal. Note that data for most of the explanatory variables is not available for, so this estimation refers only to the variables which are obtainable at bus terminals in Owerri (e.g. fuel cost data). We specify the following models for estimation in logarithmic form:

Model 1:

$$
\text { In }_{\text {totpax }}=\beta_{1} \text { InFreq }+\beta_{2} \text { InFare }+\beta_{3} \text { Dist }+\beta_{4} \text { InJtim }+ \text { eirt }
$$

Model 2:

$$
\text { In }^{D_{\text {pax }}-\mathrm{km}}=\beta 1 \text { InFreq }+\beta_{2} \text { InFare }+\beta_{3} \text { Jtim }+\beta_{4} \text { InVcap }+ \text { eirt }
$$

The explanatory variables are defined as follows:

Freq= represents the frequency of trips at route $\mathrm{r}$;

Fare $=$ available bus fare of route $r$, which is the same for all routes of the O-D city pair at time t served by the same transport company;

Jtim= journey-time performance of vehicle of respective transport company

Dist $=$ distance between origin and destination

Vcap = vehicular capacity

$\mathrm{D}_{\text {totpax }}=$ demand expressed as total number of passengers

$\mathrm{D}_{\text {pax }-\mathrm{km}}=$ demand expressed as passenger kilometer

We take the logarithm of those independent variables for which logarithmic interpretations are meaningful. This research chooses the aggregate demand forms for the market share (total number of passengers carried per day) function, and also estimates the aggregate demand model for another demand proxy (passenger-kilometer done per day) for comparisons. Routes are grouped in a city-pair by assuming that the routes with more common characteristics are more likely to be competitors, i.e. higher correlations among these routes.

\section{Estimation results}

This research estimates proposed structural demand equations models in logarithmic forms consistent with econometric modelling. The detailed estimation results, therefore, are discussed by public transport companies (those selected within the paper period) and then are combined in the summary in which the results of the OLS model with the same explanatory variables are also presented 
for comparison purpose. A multinomial logit model was estimated to determine if the travel behaviour was distant based - i.e. short distance or long distance.

Most coefficients of explanatory variables are statistically significant and have expected signs. Thus the null hypothesis $\left(\mathbf{H}_{\mathbf{0 1}}\right)$ is accepted, implying that service variables that impact on intercity travel demand are not correlated but distinct in attributes. All estimated frequency coefficients indicate that potential travelers prefer routes with high frequency, marginal effects of different frequency variables are different. The results confirm the alternate hypothesis $\left(\mathbf{H}_{\mathbf{0 2}}\right)$ that the causal factors are critical to intercity travel service demand in Nigeria, and thus a proportional frequency increase on the segment with lower frequency increases service attractiveness more than an equivalent change on higher frequency segment.

After controlling for the other factors (such as fare, frequency, journey time and vehicle capacity) the coefficients of the route dummy variable still indicate that potential travelers strongly prefer direct routes, regardless of specifications and estimation methods. This validated the alternative hypothesis $\left(\mathbf{H}_{03}\right)$ implying that public transport companies in Nigeria adopt the direct routing structure. Demand elasticities with respect to these variables and ratios of coefficients can be used to describe the structural changes over time. Whereas no specific time trends for scheduled flight time and fare effects are found, no structural changes related to other variables exist. Hence the null hypothesis $\left(\mathbf{H}_{\mathbf{0 4}}\right)$ is accepted. As shown in Table 2, most coefficients of explanatory variables are statistically significant and have expected signs. Thus the null hypothesis is accepted, implying that service variables that impact on inter-city travel demand are not correlated but distinct in attributes. Estimates from Model 1 and Model 2 method are listed in column (2) and (3).

\begin{tabular}{|c|c|c|}
\hline Variable & Model 1 & Model 2 \\
\hline Frequency (trips per day) & $1.222 * * *[0.064]$ & $1.266^{* * *}[0.476]$ \\
\hline Journey Time (minutes) & $0.380 * *[0.137]$ & $1.206 * * *[0.110]$ \\
\hline Fare (in Naira) & $-0.236^{* * *}[0.063]$ & $-0.285^{* * *}[0.043]$ \\
\hline Vehicle Capacity & & $0.165^{*}[0.083]$ \\
\hline Route Distance (kilometres) & $0.083[0.083]$ & \\
\hline Constant & $1.127^{* *}[0.406]$ & $1.590^{* * *}[\mathbf{0 . 4 7 6}]$ \\
\hline$R^{2}$ & 0.668 & 0.817 \\
\hline Adjusted $R^{2}$ & 0.858 & 0.811 \\
\hline$F$ & 67.386 & 149.381 \\
\hline
\end{tabular}

1. Model 1: Dependent variable = In (Total Number of Passengers);

2. Model 2: Dependent variable = In (Passenger-Kilometres);

3. Standard errors in brackets are robust to heteroskedasticity and serial correlation;

4. ${ }^{*} \mathrm{p}<0.05,{ }^{* *} \mathrm{p}<0.01,{ }^{* * *} \mathrm{p}<0.001$; Statistics of the first stage.

Table 2 is compiled from the SPSS 17.0 output shown in the appendix.

The models above can be expressed in the following exponential form:

Model 1:

Demand (total no. of passenger) $=1.127^{*}$ Freq $^{1.222 *}$ Jtime $^{0.380 *}$ Fare $^{-0.236 *}$ Dist $^{0.083}$

Model 2:

Demand $\left(\right.$ passenger-km) $=1.590 *$ Freq $^{1.266 *}$ Jtime $^{1.206 *}$ Fare $^{-0.285 *}$ Vcap $^{00.165}$ 
The exponents are values of elasticity from Cobb-Douglas logarithmic derivation. Although all estimated fare coefficients illustrate positive fare impacts on demand, the fare coefficients from Model 1 and Model 2 estimates are more reasonable. Fare coefficients from Model 2 estimations are larger (in absolute values) than those from Model 1 estimations. All estimated frequency coefficients indicate that potential travelers prefer routes with high trip frequency, marginal effects of different frequency variables are different. Differences in coefficient estimates among the different variables are less pronounced in the Model 1 results.

Although all coefficients of journey time indicate that travelers prefer routes with shorter journey time. The Model 2 estimates show that a one-minute increase of journey time on routes have a larger (about 1.206 times) impact of utility on direct routes.

\section{Estimated travel demand based on the derived intercity travel models}

From the research, the following intercity travel models were deduced.

Model 1: Demand (total no. of passenger) $=1.127^{*}$ Freq $^{1.222 *}$ Jtime $^{0.380 *}$ Fare $^{-0.236 *}$ Dist $^{0.083}$

Model 2: Demand (passenger-km) $=1.590 *$ Freq $^{1.266 *}$ Jtime $^{1.206 *}$ Fare $^{-0.285 *} \operatorname{Vcap}^{0.165}$

We however attempt here to show the validity of the model by plugging values of the variables of the models. Table 3 shows the results of the estimation from routes chosen from four of the transport companies operating from Owerri.

\begin{tabular}{lccccccc}
\multicolumn{6}{l}{ Table 3: Estimated Intercity Travel Demand of Selected Transport Companies in Owerri } \\
$\begin{array}{l}\text { Transport } \\
\begin{array}{l}\text { Company } \\
\text { /Route }\end{array}\end{array}$ & $\begin{array}{c}\text { Daily } \\
\text { Frequency }\end{array}$ & $\begin{array}{c}\text { Journey } \\
\text { Time }\end{array}$ & Fare & $\begin{array}{c}\text { Travel } \\
\text { Distance }\end{array}$ & $\begin{array}{c}\text { Estimated } \\
\text { Vehicle } \\
\text { Capacity }\end{array}$ & $\begin{array}{c}\text { Travel } \\
\text { Estimated } \\
\text { Dravel } \\
\text { from } \\
\text { Model 1 }\end{array}$ & $\begin{array}{c}\text { 1emand } \\
\text { Demand } \\
\text { from } \\
\text { Model 2 }\end{array}$ \\
\hline $\begin{array}{l}\text { Owerri - Awka } \\
\text { (ITC) }\end{array}$ & 3 & 2 & 1300 & 141 & 14 & 65 & 127 \\
$\begin{array}{l}\text { Owerri - Lagos } \\
\text { (GIG) }\end{array}$ & 4 & 8 & 6000 & 564 & 16 & 234 & 353 \\
$\begin{array}{l}\text { Owerri - Abuja } \\
\text { (YSG) }\end{array}$ & 5 & 9 & 7000 & 733 & 15 & 197 & 282 \\
$\begin{array}{l}\text { Owerri - Kaduna } \\
\text { (ITC) }\end{array}$ & 3 & 11 & 9000 & 812 & 30 & 98 & 147 \\
$\begin{array}{l}\text { Owerri - } \\
\text { Calabar(AITC) }\end{array}$ & 4 & 4 & 3500 & 207 & 13 & 78 & 133 \\
\hline
\end{tabular}

It is shown that in a typical day, Imo Transport Company can have a daily passenger demand of 65 passengers to Awka or will have to satisfy 127 passenger kilometrage on a daily basis; and a daily passenger demand of 98 passengers to Kaduna or will have to satisfy 147 passenger kilometrage on a daily basis with their 30-seater buses in operation. Also, the God is Good motors can do have a daily passenger demand of 234 passengers going to Lagos or the equivalent of 353 passenger kilometres in a day. In addition, the Young Shall Grow Motors have available daily passenger demand of 197 passengers to Abuja route and a 282 passenger kilometer for that same route in a typical day. Finally, The Akwa Ibom Transport Company has an estimated 78 passengers and 133 passenger kilometers for Calabar route with 13-seater buses.

However, it is possible for any would-be operator determine the expected patronage on any route of operation using the derived models from this paper. Thus this paper has come up with empirical model to assess the viability of intercity passenger transport operation in Nigeria. However, it will also help the operators in business to do a sensitivity analysis based of changes in the intercity passenger travel markets in Nigeria. It can also help transport planners to determine the trip generation capabilities of various transport companies operating in a typical town.

The main objective of the proposed framework is to model aggregate route travel behavior and there should be revealed travel data to calibrate. The actual travel data is composed of trip frequency, travel distance, travel destination, travel activity, vehicle size, travel time, etc. Because all travel choices 
are based on existing transport supply, the available travel alternatives impact travel behavior. The level of service of the alternatives is described by travel cost, travel time, frequency, comfort, convenience, safety, reliability and so on. It is required to include the attributes of the available alternatives in the dataset. In summary, the data requirement for the proposed framework is at a transport company level. Future paper should contain socio-economic characteristics of the travelers, revealed travel choice and related attributes, and the available travel alternatives.

\section{Conclusion}

The structure of the model implies that a route is more likely to compete with another route of the same 0-D city- pair than the routes of the other 0-D city pairs. The log-linear model employing passenger-kilometres is the preferred model for two reasons. First, the Model 2 models confirm the nonhomogeneous correlations among alternatives, implying that the model have unreasonable substitution patterns among alternatives. Second, the OLS estimates infer more sensible demand elasticities, and correlations of total utilities for alternatives than those of direct linear modelling method. This research develops an O-D city-pair travel demand model and applies it to the land transportation system of Nigeria. The model improves existing models by adding preferred features and employing appropriate estimation method. The main model can handle activities at a low aggregation level (route level), and can be applied to a large network system and serves as a bottom-up policy analysis tool for different scenarios. The model deals with demand generation and demand assignment in a single model. Thus, a change in a causal factor, such as a fare increase, may influence both total intercity travel demand and market shares of public transport companies in Nigeria.

\section{Funding}

The authors received no direct funding for this research.

\section{Citation information}

Dike, D. N., Ibe, C. C., Ejem, E. A., Erumaka, O., \& Chukwu, O. E. (2018). Estimation of inter-city travel demand for public road transport in Nigeria. Journal of Sustainable Development of Transport and Logistics, 3(3), 88-98. doi:10.14254/jsdtl.2018.3-3.7

\section{References}

Bourbonnais, R. (2004). Econométrie. Dunod, 5ème Edition.

Brand, D., Parody, T. E., Hsu, P. S., \& Tierney, K. F. (1992). Forecasting high-speed rail ridership. Transportation Research Record, (1341).

Bresson, G., Dargay, J., Madre, J. L., \& Pirotte, A. (2003). The main determinants of the demand for public transport: a comparative analysis of England and France using shrinkage estimators. Transportation Research Part A: Policy and Practice, 37(7), 605-627.

Bresson, G., Dargay, J., Madre, J. L., \& Pirotte, A. (2004). Economic and structural determinants of the demand for public transport: an analysis on a panel of French urban areas using shrinkage estimators. Transportation Research Part A: Policy and Practice, 38(4), 269-285.

Button, K., Ngoe, N., \& Hine, J. (1993). Modelling vehicle ownership and use in low income countries. Journal of Transport Economics and Policy, 51-67.

Camagni, R., Gibelli, M. C., \& Rigamonti, P. (2002). Urban mobility and urban form: the social and environmental costs of different patterns of urban expansion. Ecological economics, 40(2), 199216.

Dargay, J. M., \& Hanly, M. (2002). The demand for local bus services in England. Journal of Transport Economics and Policy (JTEP), 36(1), 73-91.

Davidson, W., Donnelly, R., Vovsha, P., Freedman, J., Ruegg, S., Hicks, J., ... \& Picado, R. (2007). Synthesis of first practices and operational research approaches in activity-based travel demand modeling. Transportation Research Part A: Policy and Practice, 41(5), 464-488. 
Evans, A. W., \& Mogridge, M. J. H. (1970). The Prediction of Car Ownership (Comment and Rejoinder). Journal of Transport Economics and Policy, 4(1), 89-106.

Gakenheimer, R. (1999). Urban mobility in the developing world. Transportation Research Part A: Policy and Practice, 33(7-8), 671-689.

García-Ferrer, A., Bujosa, M., de Juan, A., \& Poncela, P. (2006). Demand forecast and elasticities estimation of public transport. Journal of Transport Economics and Policy, 40(1), 45-67.

Giuliano, G., \& Dargay, J. (2006). Car ownership, travel and land use: a comparison of the US and Great Britain. Transportation Research Part A: Policy and Practice, 40(2), 106-124.

Greene, W.H. (1993). Econometric Analysis. Prentice Hall, Second Edition.

Holmgren, J. (2007). Meta-analysis of public transport demand. Transportation Research Part A: Policy and Practice, 41(10), 1021-1035.

Jansson, J. O. (1989). Car demand modelling and forecasting: a new approach. Journal of transport Economics and Policy, 23(2), 125-140.

Kain, J. F., \& Fauth, G. R. (1977). The effects of urban structure on automobile ownership and journey to work mode choices. Transportation research record, 658, 9-17.

Koppelman, F. S., \& Hirsch, M. (1989). Intercity Travel Choice Behaviour: Theory and Empirical Analysis. In Travel behaviour research: Fifth International Conference on Travel Behavior, Institut National De Recherche Sur Les Transports Et Leur Securite, Aix-En-Provence, France, (pp. 227-244).

Limtanakool, N., Dijst, M., \& Lanzendorf, M. (2003, January). International comparison of long-distance travel: the United Kingdom and the Netherlands. Presentation of 82nd Annual Meeting of the Transport Research Board.

Maddala, G. S. (2008). Introduction to Econometrics. Wiley and Sons, Third Edition.

Mcfadden, D. (1974). The Measurement of Intercity Travel Demand. Journal of Public Economics, 3, 303328.

Medlock, K. B., \& Soligo, R. (2002). Car ownership and economic development with forecasts to the year 2015. Journal of Transport Economics and Policy (JTEP), 36(2), 163-188.

Mogdridge, M. (1967). The Prediction of Car Ownership. Journal of Transport Economics and Policy, 1(1), 55-74.

Mogridge, M. J. (1989). The prediction of car ownership and use revisited: the beginning of the end?. Journal of Transport Economics and Policy, 55-74.

Orturzar, J. De D., \& Willumsen, L.G. (2006). Modelling Transport. John Wiley and Sons, 3th Edition.

Oum, T. H., Waters, W. G., \& Yong, J. S. (1992). Concepts of price elasticities of transport demand and recent empirical estimates: an interpretative survey. Journal of Transport Economics and policy, 26(2), 139-154.

Paulley, N., Balcombe, R., Mackett, R., Titheridge, H., Preston, J., Wardman, M., ... \& White, P. (2006). The demand for public transport: The effects of fares, quality of service, income and car ownership. Transport Policy, 13(4), 295-306.

Peers, J. B., \& Bevilacqua, M. (1976). Structural travel demand models: an intercity application. Transportation Research Record, 569, 124-135.

Schafer, A., \& Victor, D. G. (2000). The future mobility of the world population. Transportation Research Part A: Policy and Practice, 34(3), 171-205.

van de Coevering, P., \& Schwanen, T. (2006). Re-evaluating the impact of urban form on travel patterns in Europe and North-America. Transport policy, 13(3), 229-239.

Wardman, M. (2004). Public transport values of time. Transport policy, 11(4), 363-377. 


\section{Appendix}

MODEL 1:

Model Summary

\begin{tabular}{ccccc}
\hline Model & $\mathrm{R}$ & R Square & Adjusted R Square & $\begin{array}{c}\text { Std. Error of the } \\
\text { Estimate }\end{array}$ \\
\hline 1 & $.817^{\mathrm{a}}$ & .668 & .658 & .494
\end{tabular}

a. Predictors: (Constant), VDUMMY, FREQ, RDUMMY, FARE, DIST, JTIME

ANOVA $^{b}$

\begin{tabular}{ccccccc}
\hline & Model & Sum of Squares & $\mathrm{df}$ & Mean Square & $\mathrm{F}$ & Sig. \\
\hline \multirow{2}{*}{1} & Regression & 98.763 & 6 & 16.460 & 67.386 & $.000^{\mathrm{a}}$ \\
& Residual & 49.098 & 201 & .244 & & \\
& Total & 147.861 & 207 & & & \\
& & & & &
\end{tabular}

a. Predictors: (Constant), VDUMMY, FREQ, RDUMMY, FARE, DIST, JTIME

b. Dependent Variable: NOPASS

Coefficients a

\begin{tabular}{ccccccc}
\hline \multirow{2}{*}{ Model } & \multicolumn{2}{c}{ Unstandardized Coefficients } & \multicolumn{2}{c}{$\begin{array}{c}\text { Standardized } \\
\text { Coefficients }\end{array}$} & $\mathrm{t}$ & Sig. \\
\cline { 3 - 5 } & & $\mathrm{B}$ & Std. Error & Beta & & \\
\hline \multirow{2}{*}{1} & (Constant) & 1.127 & .406 & & 2.780 & .006 \\
& FREQ & 1.222 & .064 & .876 & 19.046 & .000 \\
& FARE & -.236 & .063 & -.247 & -3.779 & .000 \\
& JTIME & .380 & .137 & .293 & 2.775 & .006 \\
& DIST & .083 & .104 & .076 & .799 & .425 \\
& RDUMMY & .015 & .008 & .083 & 1.920 & .056 \\
& VDUMMY & .027 & .038 & .031 & .712 & .477 \\
\hline
\end{tabular}

a. Dependent Variable: NOPASS

MODEL 2:

Model Summary

\begin{tabular}{ccccc}
\hline Model & $\mathrm{R}$ & R Square & Adjusted R Square & Std. Error of the Estimate \\
\hline 1 & $.904^{\mathrm{a}}$ & .817 & .811 & .492 \\
\hline
\end{tabular}

a. Predictors: (Constant), RDUMMY, VCAP, FREQ DDUMMY, FARE, JTIME

ANOVAb

\begin{tabular}{|c|c|c|c|c|c|c|}
\hline & Model & Sum of Squares & $\mathrm{df}$ & Mean Square & $\mathrm{F}$ & Sig. \\
\hline \multirow[t]{3}{*}{1} & Regression & 216.873 & 6 & 36.145 & 149.381 & $.000^{\mathrm{a}}$ \\
\hline & Residual & 48.636 & 201 & .242 & & \\
\hline & Total & 265.509 & 207 & & & \\
\hline
\end{tabular}

a. Predictors: (Constant), RDUMMY, VCAP, FREQ DDUMMY, FARE, JTIME

b. Dependent Variable: PASSKM 


\section{Coefficients a}

\begin{tabular}{ccccccc}
\hline \multirow{2}{*}{ Model } & \multicolumn{2}{c}{ Unstandardized Coefficients } & \multicolumn{2}{c}{$\begin{array}{c}\text { Standardized } \\
\text { Coefficients }\end{array}$} & $\mathrm{t}$ & Sig. \\
\cline { 3 - 5 } & & $\mathrm{B}$ & Std. Error & Beta & & \\
\hline \multirow{2}{*}{1} & (Constant) & 1.590 & .476 & & 3.342 & .001 \\
& FREQ & 1.266 & .065 & .677 & 19.417 & .000 \\
& FARE & -.285 & .065 & -.222 & -4.411 & .000 \\
& JTIME & 1.206 & .110 & .693 & 10.951 & .000 \\
& VCAP & .165 & .083 & .069 & 1.988 & .048 \\
& DDUMMY & .711 & .120 & .296 & 5.925 & .000 \\
& RDUMMY & .000 & .007 & -.001 & -.042 & .966 \\
\hline
\end{tabular}

a. Dependent Variable: PASSKM

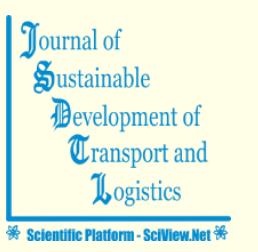

( ) 2016-2018, Journal of Sustainable Development of Transport and Logistics. All rights reserved. This open access article is distributed under a Creative Commons Attribution (CC-BY) 4.0 license.

You are free to:

Share - copy and redistribute the material in any medium or format Adapt - remix, transform, and build upon the material for any purpose, even commercially.

The licensor cannot revoke these freedoms as long as you follow the license terms.

Under the following terms:

Attribution - You must give appropriate credit, provide a link to the license, and indicate if changes were made.

You may do so in any reasonable manner, but not in any way that suggests the licensor endorses you or your use.

No additional restrictions

You may not apply legal terms or technological measures that legally restrict others from doing anything the license permits.

Journal of Sustainable Development of Transport and Logistics (ISSN: 2520-2979) is published by Scientific Publishing House "CSR", Poland,

EU and Scientific Publishing House "SciView", Poland, EU

Publishing with JSDTL ensures:

- Immediate, universal access to your article on publication

- High visibility and discoverability via the JSDTL website

- Rapid publication

- Guaranteed legacy preservation of your article

- Discounts and waivers for authors in developing regions

Submit your manuscript to a JSDTL at https://jsdtl.sciview.net/ or submit.jsdtI@sciview.net 